\title{
TRANSFORMATION OF FORM IN THE GROWTH OF MODERN JAVANESE HOUSE IN LAWEYAN SURAKARTA
}

\author{
Untung Joko CAHYONO ${ }^{\mathrm{a}}$, Bambang SETIOKO $^{\mathrm{b}}$, Titin Woro MURTINI ${ }^{\mathrm{b}}$ \\ aDepartment of Architecture, Faculty of Engineering, Sebelas Maret University, Surakarta, Indonesia \\ ${ }^{b}$ Department of Architecture, Faculty of Engineering, Diponegoro University, Semarang, Indonesia \\ E-mail:cahyono_u@yahoo.com (correspondingauthor)
}

Received 26 August 2017; accepted 21 November 2017

\begin{abstract}
Javanese house tradition grows and develops along time. In the modern era, the development of materials technology, both from the Javanese community and from the European experts, has influenced the way to build a house among the Javanese community. Visible changes are so radical in the use of materials and structural system of the building that they influence the look and shape of the house. The purpose of this research is to study the form transformation in the growth of modern Javanese houses at Kampung Batik Laweyan Surakarta. Laweyan is the traditional Javanese kampung already existing in the Kingdom Pajang long before the birth of Surakarta. Morphological analysis was used to understand deformation of modern Javanese homes developed by the generations of batik entrepreneurs in the $20^{\text {th }}$ century. Indicators of 'the Javanese origin' in modern Javanese houses are seen from the consistency of the traditional house configuration, indicated by spatial structure of pendopo, dalem, and gandok. The conclusion is that some Javanese principles still remain in developing modern houses in Laweyan, namely: (1) a house should always be developed creatively to give comfort and protection; and (2) a house should always give benefit and wealth to the owner.
\end{abstract}

Keywords: transformation of form, modern-traditional, Javanese house, Laweyan, Surakarta.

\section{Introduction}

The Javanese houses grow gradually in horizontal and vertical directions. In the developmental group of traditional Indonesian architectural forms, Javanese houses are included in the group of binubuhaffixing and ginandaduplicating (Prijotomo 2011). Binubuh begins with a basic form, and other forms are attached on it. Ginanda starts from the basic form of the building, and other similar buildings are placed around the building base, whether attached or detached. In the 20th century the growth also involved the use of modern materials, producing various forms and appearances.

This paper focuses on morphological analysis on the transformation of modern Javanese houses in Laweyan during the 20th century. Previous researches about Java houses in Laweyan have generally focused on typology (Hernowo et al. 2014; Daryanto 2005), and functional changes of the houses (Setyaningsih 2016; Hastuti 2011).
There are significant changes in three periods of time: the beginning (1900-1920s), the middle (19301960s), and the end (1970-2000s) period of the 20th century. The initial period coincided with the time when the batik business crawled up. The mid-period coincided with the time when batik business reached its peak. The last period was parallel to the time when batik business experienced a decrease and then has risen again. The question is how the values of Javanese tradition are still implemented by the generations of batik entrepreneurs in Laweyan in building their houses.

\section{Methods}

Some examples of modern Javanese houses in Laweyan were analyzed morphologically. Morphology is the study that traces the origins or the formation of a work of architecture, both related to architectural elements as well as the shape and the mass of a building as a whole. Therefore, the emphasis of the method is in the shape changing, either partly or completely, including 


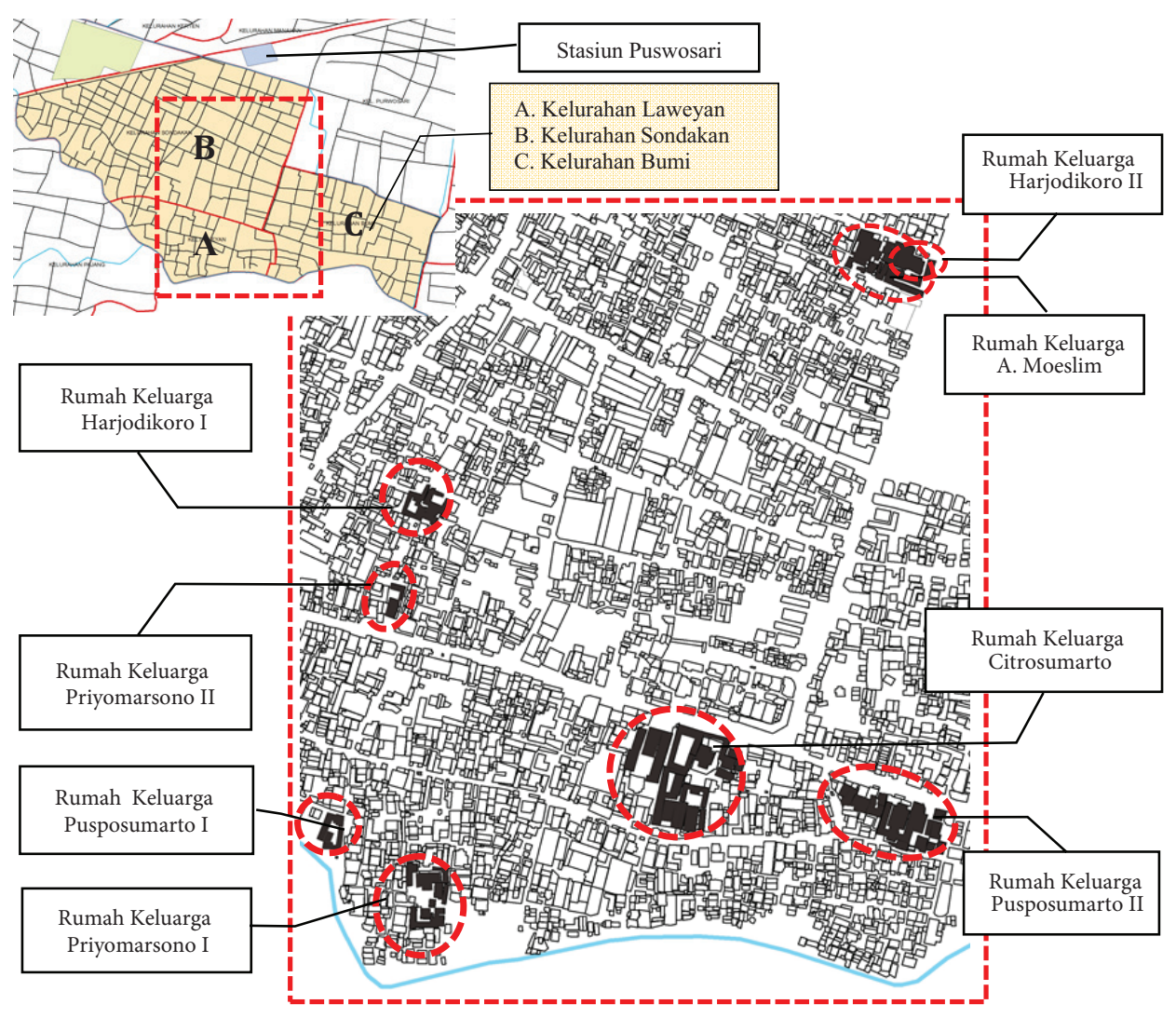

Fig. 1. The research objects are groups of houses of batik entrepreneurs families in Laweyan district, mainly at: A. Sub district of Laweyan; B. Sub district of Sondakan; and C. Sub district of Bumi Source: the Authors.

the causes and factors that influence the deformation itself (Norberg-Schultz 1988).

There are many groups of houses built by large families (trah) of batik entrepreneurs in Laweyan. The selection of houses as samples was based on the following criteria: a) the houses can be traced its "Javanese originality"; and b) there are information and informants who can tell the history of the houses.

This paper presents examples of Cokrosumarto family's houses in Laweyan sub-district, Pusposumarto family's houses in the sub-district of Bumi, and Harjodikoro family's houses in Sondakan sub-district (Fig. 1). In-depth observations were conducted by photographing, filming, measuring and redrawing of the houses. Some interviews with informants who know well about the houses were also arranged.

\section{Discussion}

\section{The growth of modern Javanese houses in Laweyan}

Laweyan community is an independent Javanese batik entrepreneurs and not depending on the power of the Surakarta Palace. Generally, for the Javanese community, the palace is the center of cultural refine- ment including the orientation of the Javanese architecture (Pitana 2014). In addition, the palace is also as the component of the traditional city structure of Java (Aliyah et al. 2016). In developing a residence for nobles and relatives in the palace neighborhood, there are strict rules that must be obeyed, especially the rules of house forms (Marlina 2017). The development of modern Javanese houses in Laweyan were much different from the settlement of the palace. The house forms of the Javanese "ordinary" people in Laweyan are more creatively expressed.

The growth of Javanese houses in Laweyan is mainly due to the increasing need for sleeping spaces and for daily activities, and for manufacturing spaces for batik. Traditionally the Javanese houses consist of two parts namely the main house and the additional house. The main house consists of pendopo and dalem while the additional house is called gandok (Santosa 2000). The gandok could have unlimited number and functions. The gandok is usually attached directly to the main house although some are detached. The modern houses of batik businessmen in Laweyan are principally not much different from the traditional Javanese houses. The modification of the main house is aimed to make rooms more spacious.The addition of gandok is made 
to meet various new needs such as to add bedrooms for family and guests (paviliun) and to create space for batik making (the factory). The growth goes horizontally and vertically.

Horizontal Growth. The addition of gandok changes the spatial layout, and it spreads in various directions (Fig. 2a, b, c). It depends on the shape and the extent of the land. The pavilion is close to the main house while the factory can be further from the main house. Like the traditional Javanese houses, the main houses remain as the center of orientation. The main house layout in the early period of the 20th century did not change horizontally. In the middle period, the size and position of main house rooms changed. In present, the main houses still face north or south, except the house Pusposumarto IV, that was newly built house in 2015 by the third generation of Pusposumarto.

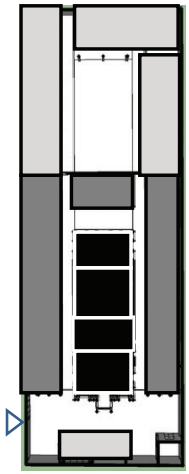

I (1920)

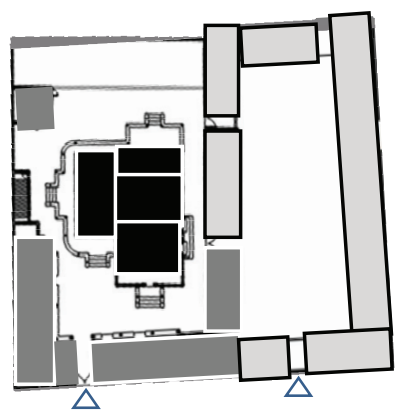

II $(1920 / 1950)$
Legend for Figures 2a, b, c:

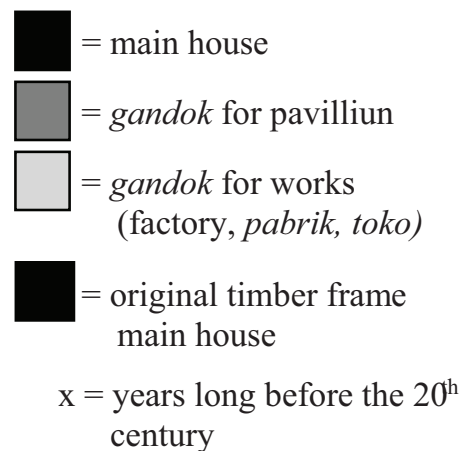

Fig. 2a. The Cokrosumarto houses. The house I was built in1920s. The house II was built in 1920s-the gandok, and in 1950s-the main house Source: the Authors.

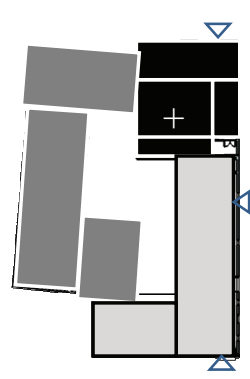

I (x/1920)

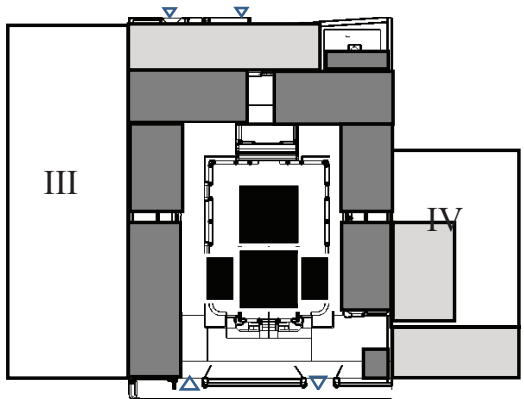

II (1940)

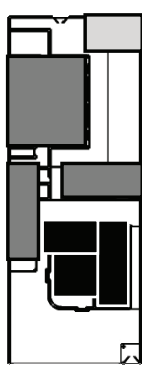

III (1950)

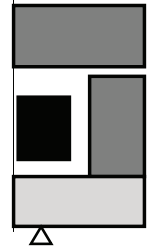

IV (2015)

Fig. 2b. The Pusposumarto houses. The house I is the first house of the families in Laweyan sub district as the pioneer of the batik merchants. The development was made in 1920. The dalem is still in an original timber frame structure. The houses II, III, and IV are the next houses in Bumi sub district, respectively built in 1940s, 1950s, and 2015s Source: the Authors.
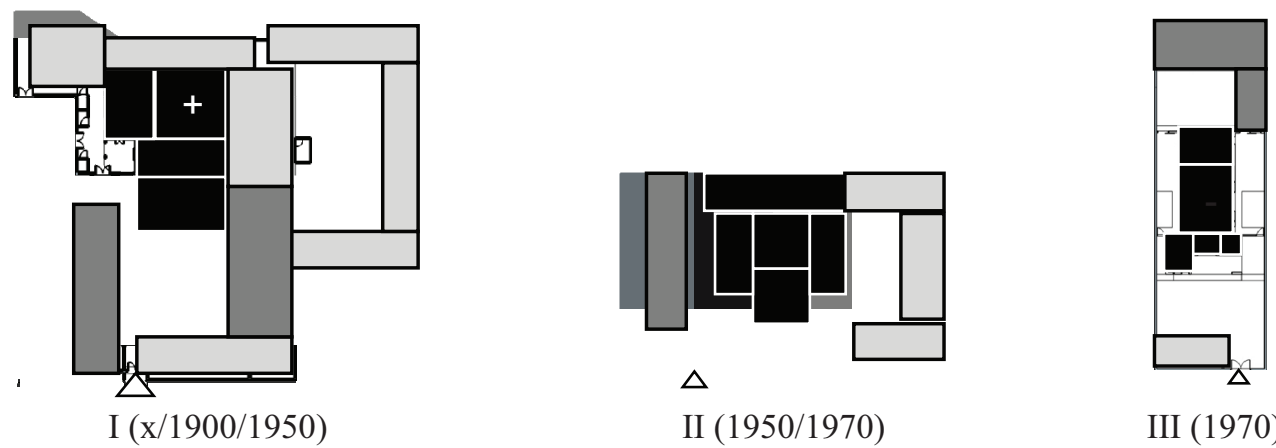

III (1970)

Fig. 2c. The Harjodikoro houses. The house I is the first house built in 1800s. The major development was made in 1900s and 1950s. The house II was built in 1950 and developed in 1970s. The house III was built in 1970s Source: the Authors. 


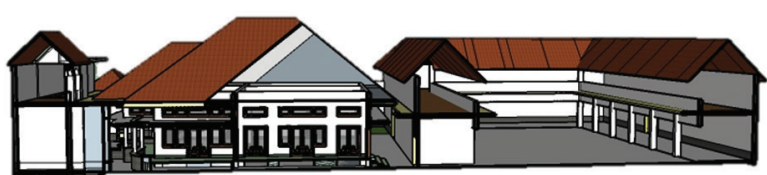

A

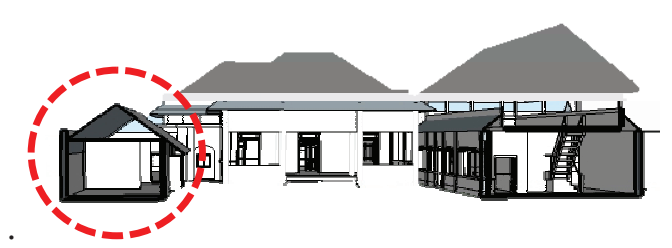

C

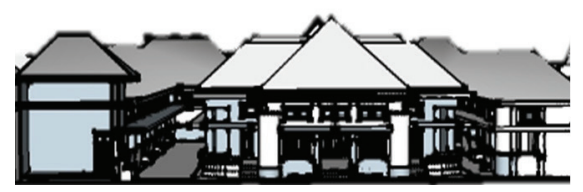

B

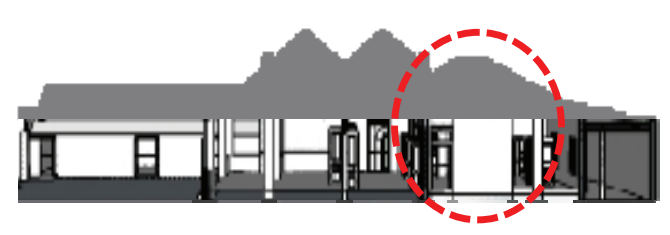

$\mathrm{D}$

Fig. 3. The Illustration of the vertical growth: A.The front elevation of Cokrosumarto's house II; B.The front elevation of Pusposumarto house II; C.The front elevation of theHarjodikoro's house I. The circled part is the original gandok, the timber frame house; D. The side elevation of Harjodikoro's house I. The circled part is the original dalem, the timber frame house

Source: the Authors.

Vertical growth. Upward growth occurred in the main house and in the gandok. In the main house, by heightening the wall, the room becomes taller and has loose and glorious impression, and thus confirms the position of the main house as the center of orientation (Fig. 3). The vertical growth of the house is also identified by the upper floor (loteng) that serves to aerate batik cloth. The loteng can be made on the gandok that serves as pavilion or factory. The outer wall of the building, the factory or gandok, also serves as a fence. From the outside, and the house is seen surrounded by a very high wall fence (4-6 meters). At the end of the 20 th century where batik production began to suffer recession, the upper floors were used for the additional bedrooms as happened in the houses of Harjodikoro II, III, and Pusposumarto IV.

\section{The transformation of forms}

Changes in the form of modern Javanese homes in Laweyan started from the use of bricks for walls and pillars. The brick layers have already been known since the era of Majapahit in the 13th century. The brick walls and pillars are combined with poles and

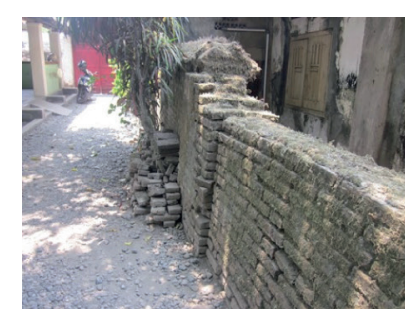

A

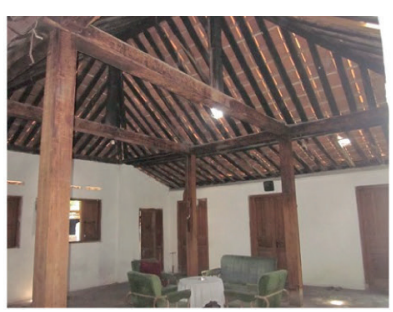

B wooden beams to make traditional house structures more stable and sturdy (Fig. 4). Furthermore, there is a very rapid development in the use of brick. The main house gets more attention in its development because the main house remains as the orientation center, so careful attention is made in choosing and applying the materials for this part. On the other hand, the additional house (gandok) is made simpler, even has potluck impression especially for the gandok that serves as a factory. The discussion on the transformation of forms covers: 1) the base and ground floor; 2) the pillars, beams, and arches; 3 ) the walls and openings; 4) the ceilings, ventilation holes, sky lights; and 5) the roof formation. The discussion covers three developmental periods namely the beginning, the middle, and the end of the 20th century.

The base and the ground floor. In the early period of the 20th century, the use of brick layer with a strong adhesive began to replace the use of outer wooden pillars. Since the house has become permanent, the foundation and floor plan should be the base for further construction. This is what distinguishes the Javanese traditional home making, which starts from determining the

Fig. 4. The ancient house is preserved at the old Kampung of Laweyan: A. The old brick construction; B. The incorporation of brickwalls with wooden structures; C.The brick pillars; and D.The exterior of the wall house Source: the Authors.

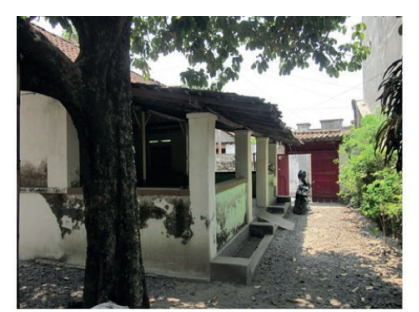

C

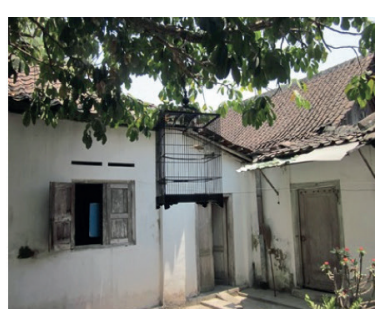

D

Source: the Authors. 


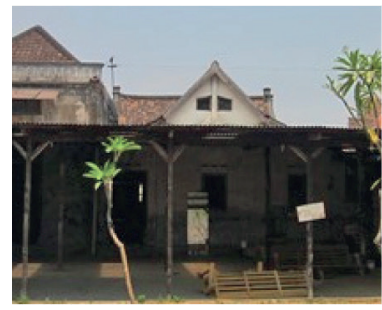

A

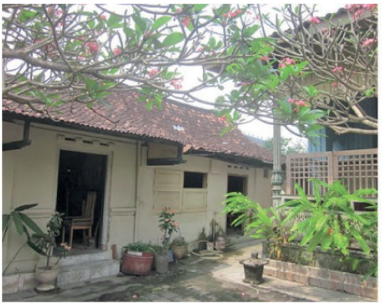

B

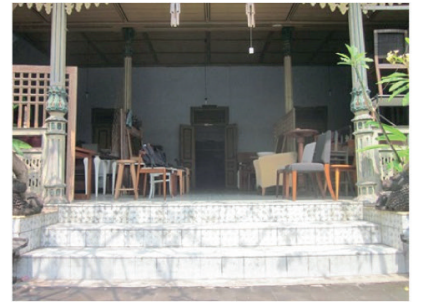

C

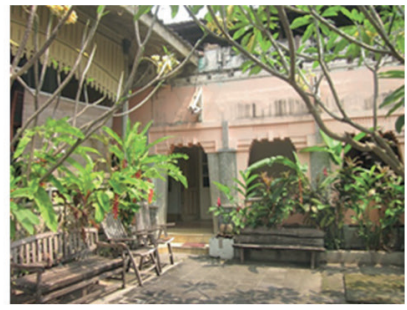

D

Fig. 5. The ground floors comparison of the Harjodikoro's house I: A. the original dalem; B. the 1900's gandok; C. the pendopo, the 1900's main house; D. the 1950's pavilion Source: the Authors.

shape of the roof (Hardiyati 2015). Heightening floor level was made to anticipate flood, humidity, and the rise of the yard and the road surface. The floor level of the main house is higher than the gandok. It shows the role of main house as the orientation center (Fig. 5).

Posts, beams, and arches. The use of wooden posts and beams is common in traditional houses' structure. After the main house was transformed by the use of bricks, the timber structure was used for the factory (Fig. 6a). Since the beginning of the 20th century, multi-storey and open house have been created for factory by making thick brick pillars with wood beams for the upstairs floor (Fig. 6b). In the same period, brick arches were used to create openings and simultaneously supporting the structures above, such as the loteng of the Cokrosumarto house II (Fig. 6c). In the mid-20th century, the reinforced concrete was available for horizontal beams to make open houses such as pendopo and veranda (Fig. 6d).

Walls and openings. The modern Javanese houses in Laweyan have experienced very significant development in an effort to make these houses as comfortable as a traditional house (Fig. 7). The brick wall houses require openings for air ventilation, natural lighting, doors, and windows. The traditional house walls were made from woven bamboos that absorb light and bring natural daylight into the building without using windows (Frick 1997). Architectural meaning of "shelter" or "pernaungan" both in traditional Javanese and in modern Javanese architecture is expressed by its open-

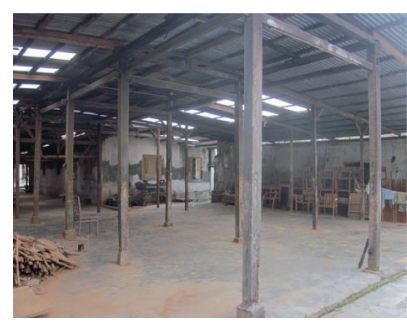

A

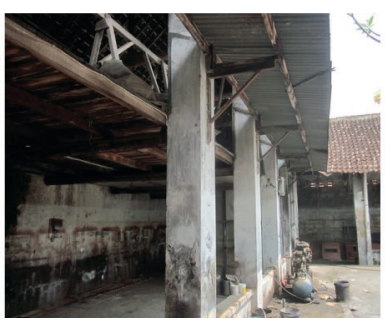

B

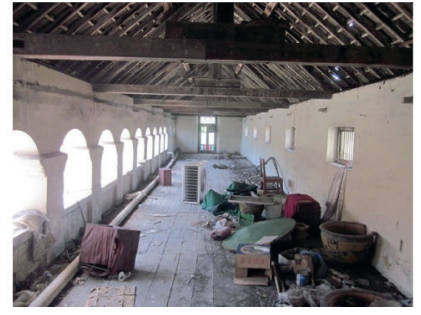

C

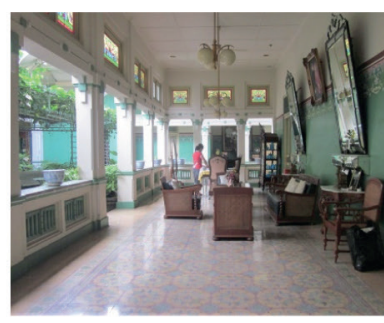

D

Fig. 6. Posts, beams, and arches: A and B. the factory of Harjodikoro houses I; C. the upper stair of loteng in the Cokrosumrto's houses II; D. the back veranda of the Cokrosumarto houses I Source: the Authors.

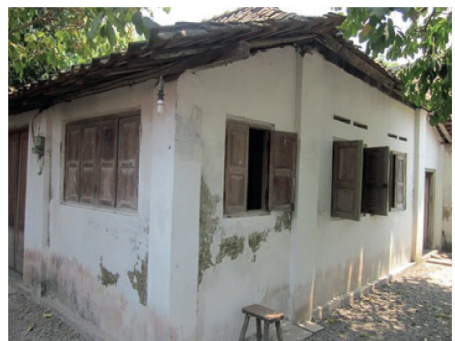

A

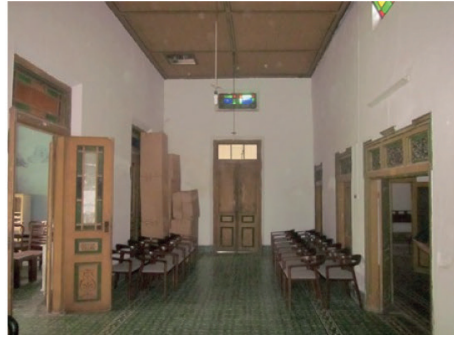

B

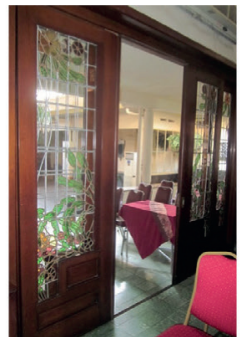

C

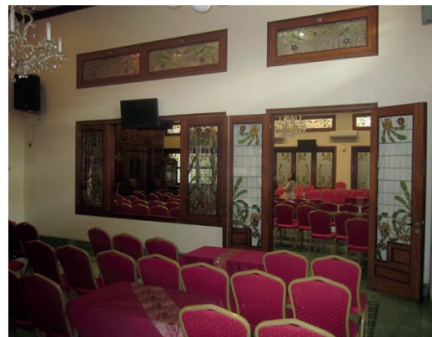

D

Fig. 7. Walls and openings. A. The old house in Laweyan; B. The Harjodikoro's house I (1900s); C and D. The Cokrosumarto's house II (1950s): The openings connecting rooms in the main house that are comfortable for wedding party Source: the Authors. 
ness and cool atmosphere embodied in the physical comfort of tropical climate and the hospitality of its inhabitants. The openings connect between the rooms (pendopo, dalem, and gandok) in the main house and make them comfortable for wedding party.

Ceilings, ventilation holes and sky lights. The old dalem does not have ceilings. The light and cool breeze can pass through the roof easily. After covered by ceiling, openings were constructed to get more daylight (Fig. 8). In the first period, the walls had few openings on the upper part of the wall for day lighting. In the mid-period, there were many openings. The ceilings reach $4.5 \mathrm{~m}$ height and they are slightly split to place holes for upward ventilation.

\section{The roof formations}

The roof of limasan-ginanda and binubuh remains applicable to the roof formation of the modern Javanese houses in Laweyan. The formation of roof for gandok and for factory tends to use the elongated limasan or kampung form and it is ended with limasan form. Climatic protection system was handled very carefully and wonderfully by applying reinforced concrete for secondary eaves. The circle shape of veranda is also possibly made. The open patio or terrace with $4.5 \mathrm{~m}$ heights wall is very comfortable shelter, but it needs more protection from the sun and heavy rain. The double-eaves system is very effective protection from heat of the sun and the heavy rain.

The early period (1900-1920s). The initial period coincided with the time when the batik business started to grow. There is no change in the spatial plan of the main house. The high walls, 4.5 meters in average, make more spacious rooms. The roof formation in this period simply puts modern limasan roofs on every house. This is an example of ginanda formation seen in the Cokrosumarto's house I and the Harjodikoro's house I. The biggest problem with this kind of roof arrangement is the leakages on the horizontal gutters.

The mid-period (1930s-1960s). This mid-period coincided with the time when batik business reached its peak. In this stage, there was an effort to avoid the number of horizontal gutters. The following figurative analysis was made to explain the transformation throughout the 20th century (Fig. 10). The main house plan of the Cokrosumarto's House II was taken as the example. The main house consists of pendopo, dalem, gandok, and verandas at the three sides. There are two ways in roofing the combined rooms of the main house. The first way is reduplication (ginanda) which was often applied in the early period of the 20th century. The second way is a combination of roofs intersecting ("saling potong" or pinotong) which was often used in the mid-20th century. The compound roof of the mid-20th

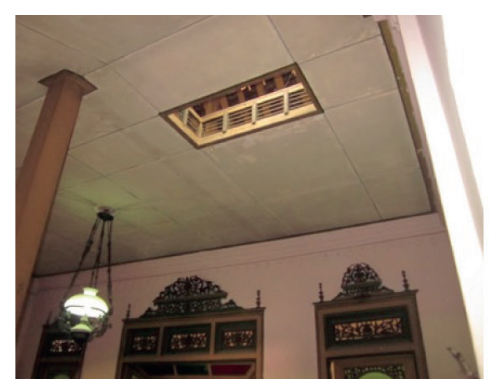

A

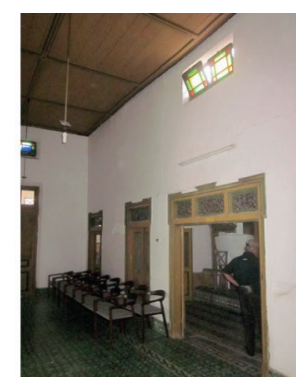

B

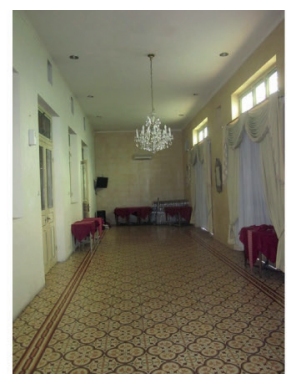

C

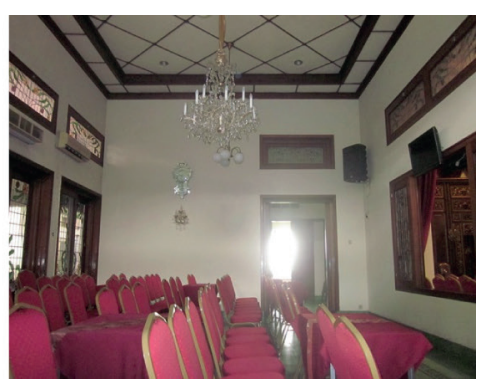

D

Fig. 8. Ceilings, sky lights and ventilation holes. The Harjodikoro's house I: A. The dalem; and B. The pringgitan. The Cokrosumarto's house II: C. The toko; and D. The gandok of the main house Source: the Authors.

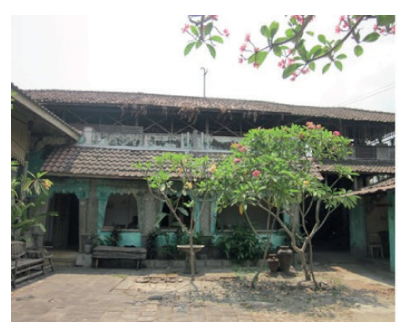

A

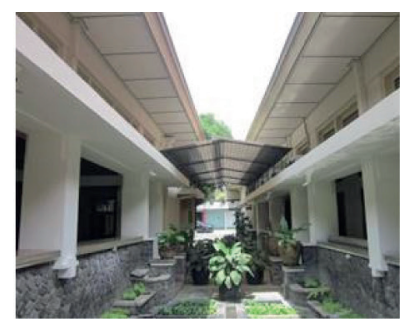

B

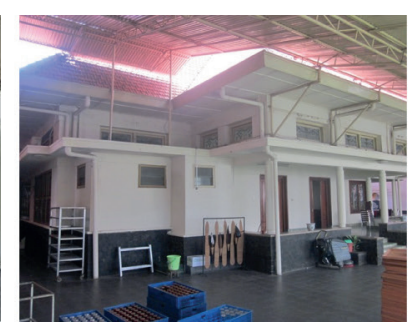

C

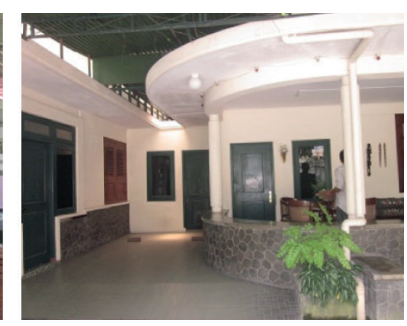

D

Fig. 9. A. The Harjodikoro's house I. B. The Pusposumarto's house I. C. The Cokrosumarto's house II.

D. The Harjodikoro's house II

Source: the Authors. 


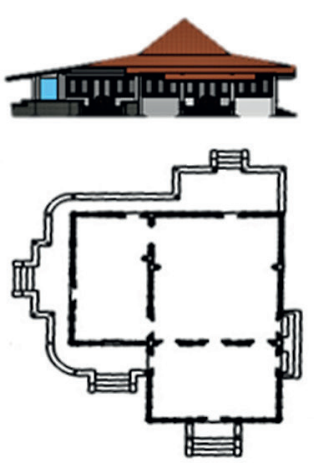

A
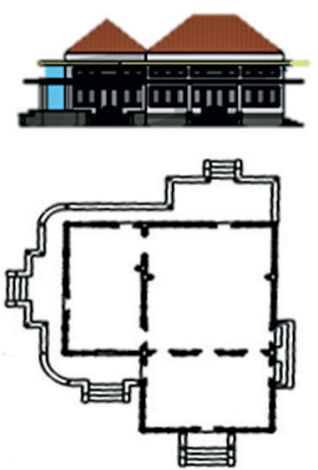

B
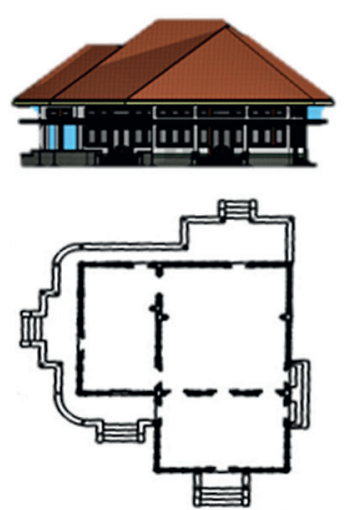

C

Fig. 10. The illustration of transformations in Javanese house forms in Laweyan. By the same plan, then apply: A. the binubuh, traditional roofs affixed; B. The ginanda, the modernlimasan roofs doubled or lined up after elevated 4.5 meters walls, built in the early period of the 20 th century; and C. the pinotong, modern limasan roofs intersection composed after elevated wall, built in the mid of the 20th century period Source: the Authors.
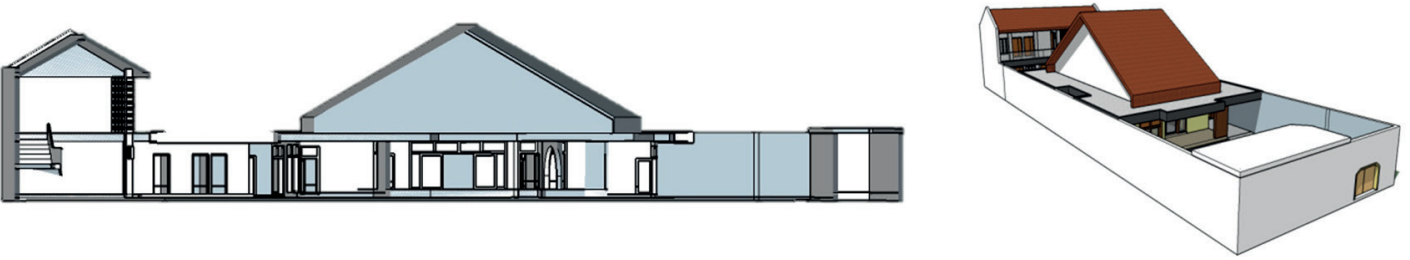

Fig. 11. The Harjodikoro house III (1970s): Unifying and simplifying roof form Source: the Authors.

century is the biggest and the most expensive one. The structure was affordable for the Laweyan entrepreneurs. The house gives the real shelter and protection like a big sturdy tree and similar to the ideal Javanese wooden house (Prijotomo 2006).

The last period (1970s-2000s). The last period was parallel to the time when the batik business experienced recession but started to rise again. The example for this period is the Harjodikoro's house III (Fig. 2c and Fig. 11). The main house consists of three parts of rooms: the front, the middle, and the rear. The front consists of an open terrace, a musholla and a guest room. The middle is the living room. The rear consists of two master bedrooms. All the rooms are covered by a big and single kampong roof. This is the process of merging (ginabung) and simplifying to a simple large kampung roof.

\section{Conclusions}

The various forms of the modern Javanese houses seen today in Laweyan are the result of thoughtful process of thinking.The shape of the houses is determined by arrangement of the base or ground floor, the treatments of the walls and openings, and the glorious forms of roofs. In the early period of the 20th century, roofs were made by binubuh and ginanda only. In the mid-period there was a transformation caused by the more advanced way in producing forms. The roofing is quite complicated; called "pinotong" derived from "potong-memotong" (intersecting). Meanwhile, in the last period, there was ginabung (unifying) to simple form. Tradition values or thoughts in how houses should be built always follow the progress of time and needs amongst the Javanese families in Laweyan. Laweyan people still maintain these ways of thinking to create a sheltering and protecting house. Sheltering is related to the way of how the house can function as the shelter, and it is also related to the use of profitable and potential nature (ngayomi). Protecting is related to how the house can provide calm atmosphere because it is strong and able to keep the dwellers from harmful environmental disturbances (ngayemi). The modern Javanese houses in Laweyan are sturdy and permanent, but they are flexible for works. It is worthy of notice that modern Javanese houses in Laweyan are the family's monuments that can provide benefits and livelihood for their dwellers over generations (ngayani). 


\section{References}

Aliyah, I.; Setioko, B.; Pradoto, W. 2016. The Roles of traditional markets as the main component of Javanese culture urban space (object of study: The City of Surakarta, Indonesia), The IAFOR Journal of Sustainability, Energy \& the Environment 3(1): 103-120.

Daryanto, T. J. 2005. Karakter Eropa pada rumah tinggal saudagar bathik di Laweyan Surakarta. Semarang: Program Pascasarjana Universitas Diponegoro.

Frick, H. 1997. Pola struktural dan teknik bangunan di Indonesia. Yogyakarta: Penerbit Kanisius.

Hardiyati. 2015. Guna dan citra detail arsitektural pada rumah Jawa. Surabaya: Institut Teknologi Sepuluh Nopember.

Hastuti, D. L. 2011. Status dan identitas sosial saudagar batik Laweyan dalam interior dalem indis di awal abad ke-20, Dewa Ruci 7(1): 140-160.

Hernowo, B.; Dewis, A.; Prawestri, A.; Roesmanto, T. 2014. The typology of Laweyan craftsmen house, Surakarta, Indonesia: an analysis based on form and function, in 30th Anniversary of the International Center of Education, 5-6 May 2014, Krakow, Poland.

Marlina, A. 2017. Ruang hunian Keraton Jawa: transformasi ndalem bangsawan dan rumah abdi dalem magersari di Baluwarti Keraton Kasunanan Surakarta: Disertasi. Semarang: Universitas Diponegoro.

Norberg-Schultz, C. 1988. Architecture: meaning and place. New York: Rizzoli.

Pitana, T. S. 2014. Dekonstruksi Makna Simbolik arsitektur Keraton Surakarta. Purwokerto: STAIN Press.

Prijotomo, J. 2006. (Re-)Konstruksi Arsitektur Jawa Griya Jawa dalam Tradisi Tanpatulisan. Surabaya: pt. wastu lanas grafika.
Prijotomo, J. 2011. Dua bangun pokok arsitektur nusantara: binubuh dan ginanda. Malang: Seminar Nasional, the Local Tripod, Jurusan Arsitektur Universitas Brawijaya.

Santosa, R. B. 2000. Omah: Membaca Makna Rumah Jawa. Yogyakarta: Yayasan Bentang Budaya.

Setyaningsih, W. 2016. Transformasi arsitektural dari kampung kota menjadi kampung wisata studi kasus: kampung wisata di Surakarta. Universitas Gadjah Mada, Yogyakarta.

\section{UNTUNG JOKO CAHYONO}

Lecturer

Department of Architecture, Sebelas Maret University

Student of Doctoral Program of Architecture and Urbanism

Diponegoro University

cahyono_u@yahoo.com

\section{BAMBANG SETIOKO}

Professor of Architecture

Supervisor of Doctoral Program of Architecture and Urbanism Diponegoro University

keliek2000@yahoo.com

\section{TITIN WORO MURTINI}

Doctor of Architecture

Supervisor of Doctoral Program of Architecture and Urbanism Diponegoro University

titien_wm@yahoo.com 